H. Dong • M. Kumar · Y. Zhang • A. Gyulkhandanyan •

Y.-Y. Xiang • B. Ye · J. Perrella $\cdot$ A. Hyder

N. Zhang - M. Wheeler $\cdot$ W.-Y. Lu $\cdot$ Q. Wang

\title{
Gamma-aminobutyric acid up- and downregulates insulin secretion from beta cells in concert with changes in glucose concentration
}

Received: 18 August 2005 / Accepted: 1 November 2005 / Published online: 31 January 2006

C) Springer-Verlag 2006

\begin{abstract}
Aims/hypothesis: The role of gamma-aminobutyric acid (GABA) and A-type GABA receptors $\left(\mathrm{GABA}_{\mathrm{A}} \mathrm{Rs}\right)$ in modulating islet endocrine function has been actively investigated since the identification of GABA and $\mathrm{GABA}_{\mathrm{A}}$ Rs in the pancreatic islets. However, the reported effects of $\mathrm{GABA}_{\mathrm{A}} \mathrm{R}$ activation on insulin secretion from islet beta cells have been controversial. Methods: This study examined the hypothesis that the effect of GABA on beta cell insulin secretion is dependent on glucose concentration. Results: Perforated patchclamp recordings in INS- 1 cells demonstrated that GABA, at concentrations ranging from 1 to $1,000 \mu \mathrm{mol} / 1$, induced a transmembrane current $\left(\mathrm{I}_{\mathrm{GABA}}\right)$ which was sensitive to the $\mathrm{GABA}_{\mathrm{A}} \mathrm{R}$ antagonist bicuculline. The current-voltage relationship revealed that $\mathrm{I}_{\mathrm{GABA}}$ reversed at $-42 \pm 2.2 \mathrm{mV}$, independently of glucose concentration. Nevertheless, the glucose concentration critically controlled the membrane potential $\left(V_{\mathrm{M}}\right)$, i.e., at low glucose $(0$ or $2.8 \mathrm{mmol} / \mathrm{l})$ the
\end{abstract}

H. Dong $\cdot$ M. Kumar $\cdot$ Y. Zhang · A. Gyulkhandanyan

Y.-Y. Xiang · B. Ye · M. Wheeler · W.-Y. Lu · Q. Wang Department of Physiology, University of Toronto,

Toronto, ON, Canada

H. Dong · Y.-Y. Xiang $\cdot$ B. Ye $\cdot$ W.-Y. Lu Department of Anaesthesia, University of Toronto,

Toronto, ON, Canada

M. Kumar · Y. Zhang · A. Gyulkhandanyan ·

J. Perrella $\cdot$ M. Wheeler $\cdot$ Q. Wang

Department of Medicine, University of Toronto,

Toronto, ON, Canada

M. Kumar · Y. Zhang · J. Perrella · A. Hyder ·

N. Zhang $\cdot$ Q. Wang $(\bowtie)$

St. Michael's Hospital,

Room 7005, Queen Wing, 30 Bond Street,

Toronto, ON, Canada

e-mail: qinghua.wang@utoronto.ca

Tel.: +1-416-8646060x6767

Fax: +1-416-8646043

H. Dong · Y.-Y. Xiang · B. Ye · W.-Y. Lu Sunnybrook \& Women's College Health Sciences Centre, Toronto, ON, Canada endogenous $V_{\mathrm{M}}$ of INS-1 cells was below the $\mathrm{I}_{\mathrm{GABA}}$ reversal potential and at high glucose $(16.7$ or $28 \mathrm{mmol} / \mathrm{l})$, the endogenous $V_{\mathrm{M}}$ of INS-1 cells was above the $\mathrm{I}_{\mathrm{GABA}}$ reversal potential. Therefore, GABA dose-dependently induced membrane depolarisation at a low glucose concentration, but hyperpolarisation at a high glucose concentration. Consistent with electrophysiological findings, insulin secretion assays demonstrated that at $2.8 \mathrm{mmol} / 1$ glucose, GABA increased insulin secretion in a dose-dependent fashion $(p<0.05, n=7)$. This enhancement was blocked by bicuculline $(p<0.05, n=4)$. In contrast, in the presence of $28 \mathrm{mmol} / 1$ glucose, GABA suppressed the secretion of insulin $(p<0.05, n=5)$. Conclusions/interpretation: These findings indicate that activation of $\mathrm{GABA}_{\mathrm{A}} \mathrm{Rs}$ in beta cells regulates insulin secretion in concert with changes in glucose levels.

Keywords Calcium influx - Gamma-aminobutyric acid . Glucose $\cdot$ INS-1 cells $\cdot$ Insulin secretion $\cdot$ Perforated patch clamp

Abbreviations $\mathrm{GABA}_{\mathrm{A}} \mathrm{R}$ : A-type GABA receptor $\left[\mathrm{Ca}^{2+}\right]_{\mathrm{i}}$ : intracellular $\mathrm{Ca}^{2+}$ concentration $\cdot I-V$ : current voltage $\cdot \mathrm{GABA}$ : gamma-aminobutyric acid $\cdot V_{\mathrm{M}}$ : membrane potential $\cdot \mathrm{I}_{\mathrm{GABA}}$ : GABA-induced transmembrane current

\section{Introduction}

Gamma-aminobutyric acid (GABA), which is synthesised from glutamic acid by the rate-limiting enzyme GAD, is a major inhibitory neurotransmitter in the mammalian central nervous system [1]. GABA induces rapid inhibition primarily by activating the A-type GABA receptor $\left(\mathrm{GABA}_{\mathrm{A}} \mathrm{R}\right)$ [2], a heteropentameric $\mathrm{Cl}^{-}$ion channels complex [3]. In most cases, activation of $\mathrm{GABA}_{\mathrm{A}} \mathrm{R}$ in neurons results in membrane hyperpolarisation as a consequence of an inward $\mathrm{Cl}^{-}$flux [3].

The concentrations of GABA and GAD and the density of $\mathrm{GABA}_{A} \mathrm{R}$ in pancreatic islets are comparable with those 
encountered in the central nervous system [4-8], suggesting that the $\mathrm{GABA}-\mathrm{GABA}_{\mathrm{A}} \mathrm{R}$ system plays a role in modulating islet endocrine functions. In the pancreas, GABA is primarily produced by insulin-secreting beta cells [9-11] and probably by the glucagon-containing alpha cells $[9,12] . \mathrm{GABA}_{\mathrm{A}}$ Rs are expressed in both beta and alpha cells [13-15], suggesting that GABA modulates pancreatic endocrine function in an autocrine and paracrine manner [16-18]. In pancreatic beta cells, GABA is associated with synaptic-like microvesicles that are distinct from the insulin-containing large dense-core vesicles $[10,11]$. Release of GABA from beta cells appears to be regulated by nutrients [19] including glucose [19-21].

The effect of GABA on insulin secretion from the beta cells has also been controversial. For example, perfusion studies using rat and dog pancreas have shown that GABA inhibits arginine-stimulated insulin release [16, 21]. Other studies demonstrate that both $\mathrm{GABA}$ and $\mathrm{GABA}_{\mathrm{A}} \mathrm{R}$ agonists have no detectable effect on insulin secretion in perfused rat pancreas $[22,23]$. However, GABA-induced increases in insulin release were observed in rat pancreas and isolated human insulinoma cells [13, 24, 25].

The direction of the $\mathrm{GABA}_{\mathrm{A}} \mathrm{R}$-mediated $\mathrm{Cl}^{-}$current depends on membrane potential $\left(V_{\mathrm{M}}\right)$, which, in pancreatic beta cells, is critically regulated by extracellular glucose $[26,27]$. We hypothesise that the effect of GABA on insulin secretion from beta cells is dependent on the extracellular glucose concentration. Using perforated patch-clamp recordings and insulin secretion assays, we examined in insulin-secreting INS-1 cells the effects of GABA on $V_{\mathrm{M}}$ and insulin secretion in the presence of different levels of glucose. Our results indicate that, depending on the extracellular glucose levels, GABA can exert either excitatory or inhibitory effects on beta cells.

\section{Materials and methods}

Cell culture

INS-1 cells (passage 50-65) were maintained in RPMI 1640 medium (Invitrogen, Burlington, ON, Canada) containing fetal bovine serum $(10 \% \mathrm{v} / \mathrm{v}), 100 \mathrm{Units} / \mathrm{ml}$ penicillin G sodium, $100 \mu \mathrm{g} / \mathrm{ml}$ streptomycin sulphate, $55 \mathrm{mg} / 500 \mathrm{ml}$ sodium pyruvate, $1.14 \mathrm{~g} / 500 \mathrm{ml}$ HEPES, and $1.7 \mu \mathrm{l} / 500 \mathrm{ml} \beta$-mercaptoethanol at $37^{\circ} \mathrm{C}$ in an atmosphere of humidified air (95\%) and $\mathrm{CO}_{2}(5 \%)$. In studies involving serum-starvation, serum was replaced by $0.1 \%$ BSA in RPMI 1640 without glucose.

\section{RT-PCR}

Total cellular RNA was extracted from confluent $10-\mathrm{cm}$ plates of INS-1 cells using Trizol (Invitrogen Life Technologies, CA, USA) following the manufacturer's instructions. GABA $\mathrm{R}$ mRNA transcripts were detected using a one-step RT-PCR kit (Qiagen). Briefly, 100 ng total RNA were used in $25-\mu$ l one-step RT-PCR reactions containing $0.4 \mathrm{mmol} / 1 \mathrm{dNTPs}$ and $0.6 \mu \mathrm{mol} / 1$ of each primer. The template was omitted for the negative control. Thermocycler conditions were $50^{\circ} \mathrm{C}$ for $30 \mathrm{~min}, 95^{\circ} \mathrm{C}$ for $15 \mathrm{~min}$, and 35 cycles at $94^{\circ} \mathrm{C}$ for $30 \mathrm{~s}, 60^{\circ} \mathrm{C}$ for $30 \mathrm{~s}$, and $72^{\circ} \mathrm{C}$ for $1 \mathrm{~min}$. This was followed by a 10 -min extension at $72^{\circ} \mathrm{C}$. The RT-PCR products were separated on a $1 \%$ agarose gel and visualised with ethidium bromide. The $\mathrm{GABA}_{\mathrm{A}} \mathrm{R}$ gene-specific primers used were as follows: $\alpha 1$ FP: cgggaagaagctatggaca; $\alpha 1$ RP: ccactcatagacaacttctgc; $\alpha 2$ FP: tctagacagacttctggatgg; $\alpha 2$ RP: agagtcagaagcattg taagtc; $\alpha 3$ FP: cccagatattcctgacgatag; $\alpha 3$ RP: tgagccatcct gagctactt; $\beta 1$ FP: cgactgctcaaaggatatgac; $\beta 1$ RP: agtga tagtcgtggatatgcc; $\beta 2$ FP: gctgtctgtgctcagagtgt; $\beta 2$ RP: gtgactgcattgtcatcgcc; $\beta 3$ FP: acggtcgacaagctgttgaa; $\beta 3$ RP: tcgagcagcagatgcatc; $\gamma 1$ FP: gtccagatataggcgtgaga; $\gamma 1$ RP: ctccagtacttaggatcagc; $\gamma 2$ FP: gcattggtccagtgaatgct; $\gamma 2$ RP: ggaatgtaggtctggatggt; $\gamma 3$ FP: acagcattggtcctgtgt ca; $\gamma 3$ RP: caaactgatagagecgccat.

\section{Immunoblotting}

Cells were lysed in buffer containing 1\% Triton X-100 and protease and phosphatase inhibitors, as previously described [28]. Proteins $(50 \mu \mathrm{g})$ were separated by $10 \%$ SDSPAGE and electrotransferred onto a nitrocellulose filter (0.2 $\mu \mathrm{m}$; Bio-Rad Laboratories, Hercules, CA, USA). After probing with mouse anti-beta2/3 isoforms of $\mathrm{GABA}_{\mathrm{A}} \mathrm{R}$ IgG (1:1,000; Upstate Biotechnology, Lake Placid, NY, USA), the proteins were visualised with horseradish peroxidase-conjugated goat anti-mouse $\operatorname{IgG}(1: 5,000$; Upstate Biotechnology) using an electrochemiluminescence detection technique (Amersham, Piscataway, NJ, USA), as described previously [28].

\section{Immunochemistry}

Cells grown on glass coverslips in 12-well plates were fixed with paraformaldehyde (3.7\% in PBS) and permeabilised with $0.2 \%$ Triton X-100. After incubation with $5 \%$ goat serum and $1 \%$ BSA (in PBS) for $60 \mathrm{~min}$, cells were incubated with mouse antibodies against beta2/3 $\mathrm{GABA}_{\mathrm{A}} \mathrm{R}$ subunits (1:100; Upstate Biotechnology) overnight at $4^{\circ} \mathrm{C}$. After washing, cells were incubated with $\mathrm{Cy} 3$-conjugated goat anti-mouse IgG (1:500, 30 min; Jackson ImmunoResearch Laboratories, West Grove, PA, USA). Images were visualised using a Leica TCS 4D laser confocal fluorescence microscope.

\section{Electrophysiology}

Perforated patch recordings were performed at room temperature $\left(23-25^{\circ} \mathrm{C}\right)$. One hour before recording, cells were bathed in the standard glucose-free extracellular solution containing (in mmol/l) $145 \mathrm{NaCl}, 1.3 \mathrm{CaCl}_{2}$, $5.4 \mathrm{KCl}, 25 \mathrm{HEPES}$, (pH 7.4). Recordings were performed using an Axopatch-1D amplifier (Axon Instruments, Foster 
City, CA, USA). Electrodes (3-5 M $\Omega$ ) were constructed from thin-walled glass (1.5 mm diameter; World Precision Instruments, Sarasota, FL, USA) using a two-stage puller (PP-830; Narishige, East Meadow, NY, USA). The standard intracellular solution for perforated patch recording consisted of (in mmol/l) $150 \mathrm{~K}$-gluconate, $10 \mathrm{KCl}, 10$ $\mathrm{KOH}, 10 \mathrm{HEPES}, 2 \mathrm{MgCl}_{2}$ and $1 \mathrm{CaCl}_{2}$. After addition of the pore-forming agent amphotericin B (Sigma-Aldrich Corp., Buchs, Switzerland) [27], the $\mathrm{pH}$ of the intracellular solution was adjusted to 7.30 (with $\mathrm{KOH}$ ) and the osmolarity was corrected to a range of 310-315 mOsm.

Perforated recordings started under voltage-clamp mode. The effect of amphotericin B was observed as a constant decrease in serial resistance after the electrode seal. In most of the recordings, the resistance declined to a value ranging from 28 to $30 \mathrm{M} \Omega$ within 5-15 min after the seal, and then stabilised for 45-60 min. All perforated patch recordings began when the serial resistance had attained values below $28 \mathrm{M} \Omega$. To monitor a possible formation of whole-cell configuration, a testing voltage-ramp (a gradual voltage change from -80 to $60 \mathrm{mV}$ in $1.5 \mathrm{~s}$ ) was applied to the cell at the start of recording, and approximately every $10 \mathrm{~min}$ during the recording. With this testing protocol, a sigmoidshaped current-voltage $(I-V)$ curve was seen under stable perforated patch recordings, whereas a linear $I-V$ relationship gradually appeared after whole-cell configuration. If a sudden change in the $I-V$ relationship occurred, the recording was not used for the study. To measure the $\mathrm{GABA}_{\mathrm{A}} \mathrm{R}$-channel activity in INS-1 cells, perforated patch recordings were carried out under voltage-clamp mode and cells were held at $-60 \mathrm{mV}$ unless otherwise indicated. Different concentrations of GABA $(1.0-1000 \mu \mathrm{mol} / \mathrm{l})$ were focally applied to the recorded cells by means of a computer-controlled multi-barrelled perfusion system (SF-77B; Warner Instruments, Hamden, CT, USA). To investigate the effect of GABA on the excitability of INS-1 cells in different concentrations of glucose, changes in the $V_{\mathrm{M}}$ were evaluated via current-clamp recordings. The electrical signals were digitised, filtered $(1 \mathrm{kHz})$, and acquired on-line using the program Clampex and analysed off-line by means of the program Clampfit (Axon Instruments).

Intracellular $\mathrm{Ca}^{2+}$ measurement

Intracellular $\mathrm{Ca}^{2+}$ concentration $\left(\left[\mathrm{Ca}^{2+}\right]_{\mathrm{i}}\right)$ was measured using Fura 2-AM (Molecular Probes). Cells grown on coverslips (70-80\% confluency) were loaded with Fura-2 AM $(3 \mu \mathrm{mol} / \mathrm{l})$ in a medium containing (in $\mathrm{mmol} / \mathrm{l}$ ) $130 \mathrm{NaCl}, 5 \mathrm{KCl}, 2 \mathrm{CaCl}_{2}, 1 \mathrm{MgCl}_{2}, 5 \mathrm{NaHCO}_{3}$ and 10 HEPES, pH 7.4 for $50 \mathrm{~min}$ at $37^{\circ} \mathrm{C}$. Cells were washed and transferred to an open chamber equipped with a TC-324B Heater Controller (Warner Instruments) and perfused with the same medium at $1 \mathrm{ml} / \mathrm{min}\left(36-37^{\circ} \mathrm{C}\right)$ while the recordings were made using an Olympus BX51W1 fluorescent microscope. Cells were excited by dual excitation at 340/380 nm using a DeltaRam high-speed monochromator (Photon Technology International) and the emissions were detected at $510 \mathrm{~nm}$ by a band pass filter. The system was equipped with ImageMaster 3 software for control of the monochromator, the video camera, and collecting data.

\section{Insulin secretion}

Insulin concentrations were measured using a rat insulin RIA kit (Linco Research, St. Louis, MO, USA) as previous described [28]. INS-1 cells grown in 24-well plates to 85$90 \%$ confluency were rinsed twice and incubated with $\mathrm{KRB}$ (containing, in mmol/l, $115 \mathrm{NaCl}, 5 \mathrm{KCl}, 24 \mathrm{NaHCO}_{3}$, $2.5 \mathrm{CaCl}_{2}, 1 \mathrm{MgCl}_{2}, 10 \mathrm{HEPES}$, and $0.1 \% \mathrm{BSA}$ ) for

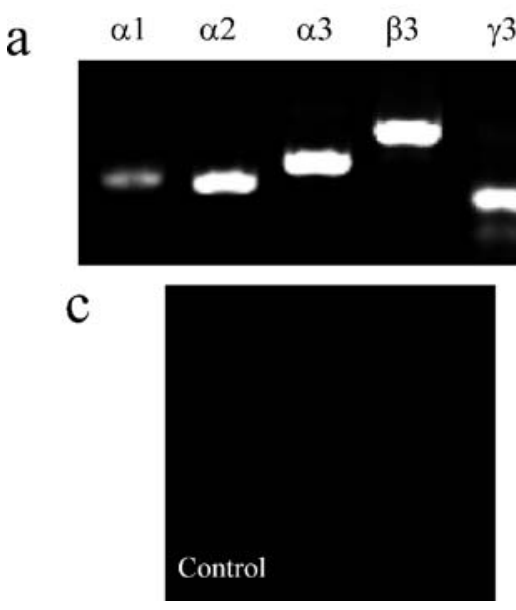

Fig. 1 Expression of $\mathrm{GAB}_{\mathrm{A}} \mathrm{A}$ receptors in INS-1 cells. a RT-PCR to detect different $\mathrm{GABA}_{\mathrm{A}} \mathrm{R}$ subunit nucleotide sequences (See Materials and methods). Total RNA from INS-1 cells were used in one-step RT-PCR reactions using specific primers for the alpha ${ }_{1-3}$, beta $_{1-3}$, and gamma $_{1-3}$ subunits to detect expression of the different subunits. In the control reaction, the template was omitted.

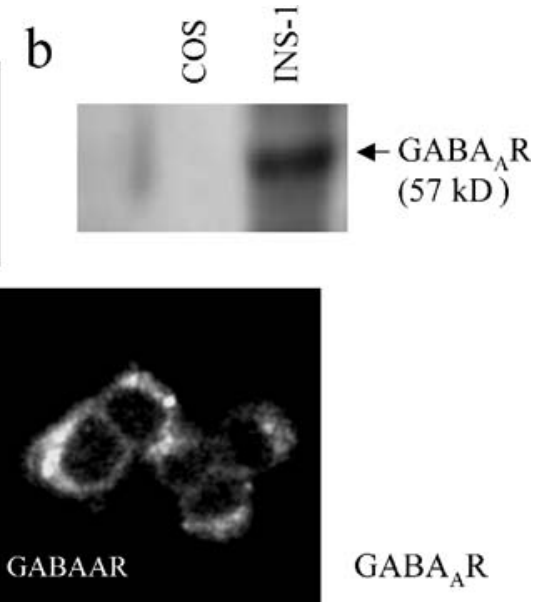

b Western blot on INS- 1 cell lysates (50- $\mu$ g protein) using a specific antibody against the beta $a_{2 / 3}$ subunits of the $\mathrm{GABA}_{\mathrm{A}} \mathrm{R}$. COS cell lysates were used as control. c Immunocytochemistry of INS-1 cells using the antibody against beta $2 / 3$ subunits of the $\mathrm{GABA}_{\mathrm{A}} \mathrm{R}$. COS cells were used in the control staining 
60 min. Cells were incubated in KRB in the presence of various concentrations of glucose (dextrose; Merck KgaA, Darmstadt, Germany) and/or GABA (Sigma, St. Louis, MO, USA) as indicated. After $30 \mathrm{~min}$ of incubation, the media were collected and insulin levels measured by RIA using the rat insulin RIA kit according to the manufacturer's instructions. The insulin secretion was normalised to the cellular protein content. Protein was determined using the Bio-Rad protein assay kit (Bio-Rad Laboratories, CA, USA).

\section{Statistical analysis}

Data are expressed as means \pm SEM. For insulin secretion assays, the number of samples and separate experiments are described in the figure legends. Statistical difference between groups was analysed by ANOVA followed by a Student-Newman-Keuls test to estimate the differences between each pair of groups when applicable. For electrophysiological analysis, data were compared with Student's unpaired or paired $t$-test where appropriate. A $p$ value $<0.05$ was considered as significant. Statistical analyses were performed using SigmaStat from Jandel Scientific Software (San Rafael, CA, USA).

\section{Results}

Expression of $\mathrm{GAB}_{\mathrm{A}} \mathrm{A}$ receptor in INS-1 cells

RT-PCR experiments demonstrated that INS-1 cells express transcripts of $\mathrm{GABA}_{\mathrm{A}} \mathrm{R}$ subunits alpha 1, alpha 2, alpha 3, beta 3 and gamma 3 (Fig. 1a). It is known that in neurons, a functional $\mathrm{GABA}_{\mathrm{A}} \mathrm{R}$ is usually a pentamer composed of two alpha, two beta and one gamma receptor subunits [2]. Thus, INS-1 cells appear to possess the necessary subunits for a functional $\mathrm{GABA}_{\mathrm{A}} \mathrm{R}$. Furthermore, Western blot analysis using a specific antibody directed against the beta $2 / 3$ subunits of $\mathrm{GABA}_{A} \mathrm{R}$ detected the expression of $\mathrm{GABA}_{\mathrm{A}} \mathrm{R}$ proteins in INS-1 cells (Fig. 1b). Expression and membrane localisation of $\mathrm{GABA}_{\mathrm{A}} \mathrm{R}$ were also confirmed by immunostaining and confocal imaging studies (Fig. 1c). In addition, immunostaining of rat pancreas sections using anti-alpha1 and beta $2 / 3$ subunit antibodies showed that islet beta cells express alpha 1 and beta 2 or beta 3 subunits (data not shown). a

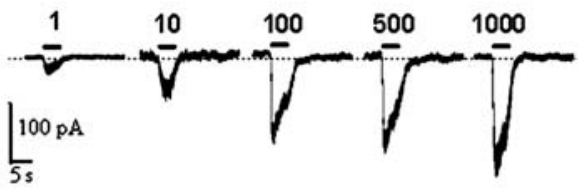

$\mathrm{b}$

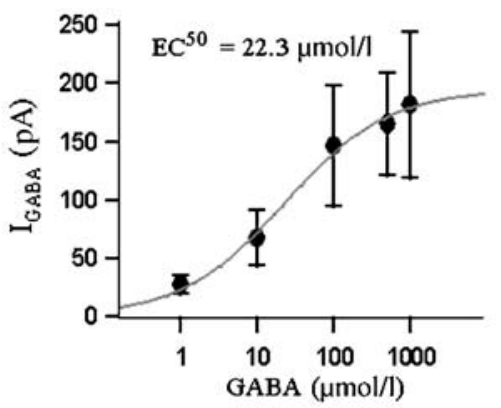

$\mathrm{C}$

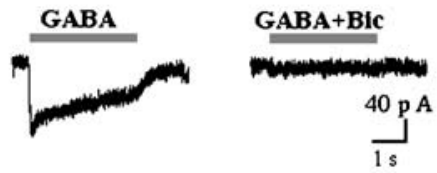

$\mathrm{d}$

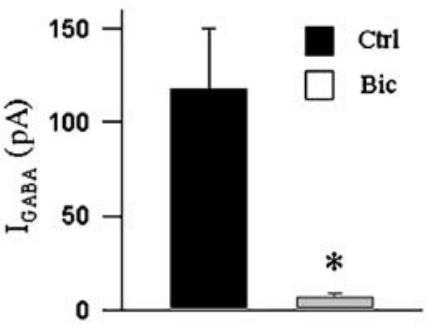

e

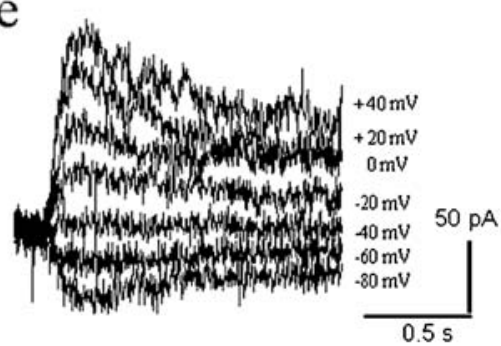

f

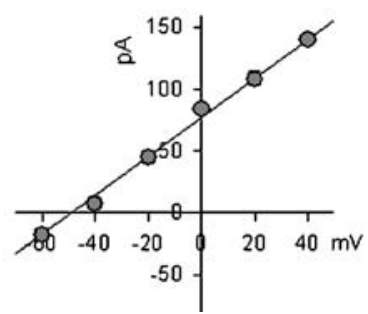

g

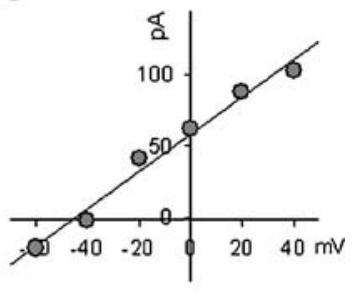

Fig. 2 Transmembrane current evoked by GABA. a GABA-evoked currents in INS-1 cells via activation of $\mathrm{GABA}_{\mathrm{A}}$ Rs. In a perforated voltage-clamp mode, when cells were voltage clamped at $-60 \mathrm{mV}$, fast application of GABA (b) dose-dependently evoked inward currents ( $n \geq 8$ cells at each testing concentration of GABA). $\mathbf{c}$ The effect of $\mathrm{GABA}_{\mathrm{A}} \mathrm{R}$ antagonist bicuculline (Bic, $50 \mu \mathrm{mol} / \mathrm{l}$ ) on GABA (100 $\mu \mathrm{mol} / \mathrm{l})$-induced current. The peak amplitude (d) of GABA currents in the absence $(\mathrm{Ctrl})$ and presence of bicuculline was plotted (Ctrl: $117 \pm 33 \mathrm{pA}, n=15$; Bic: $7 \pm 2 \mathrm{pA}, n=4 ; p<0.05)$. e In the absence of glucose, GABA $(100 \mu \mathrm{mol} / \mathrm{l})$ evoked inward and outward currents in the same INS-1 cell when held at different membrane potentials. $f$ The reversal potential for GABA currents in the absence of glucose was determined by analysing the currentvoltage relationship $(-42 \pm 2.2 \mathrm{mV}, n=6$ cells). $\mathrm{g}$ In the presence of $16.7-\mathrm{mmol} / \mathrm{l}$ glucose, GABA currents were reversed at $-43 \mathrm{mV}$ 
$\mathrm{GABA}_{\mathrm{A}} \mathrm{Rs}$ in INS-1 cells are functional

To investigate whether the $\mathrm{GABA}_{\mathrm{A}}$ Rs in INS-1 cells were functional, we applied different concentrations of GABA to the cells by means of a fast perfusion system, and measured transmembrane currents using voltage-clamp recording techniques (Fig. 2a). We found that when held at $-60 \mathrm{mV}$, about $60 \%$ of cells generated visible inward currents in response to $1 \mu \mathrm{mol} / \mathrm{l} \mathrm{GABA}$. Yet, currents were generated in all tested cells when GABA concentrations were higher than $3 \mu \mathrm{mol} / 1$. The GABA-induced currents were concentration-dependent (Fig. 2a,b), with an $\mathrm{EC}_{50}$ of $22.3 \mu \mathrm{mol} / 1$ (Fig. 2b). We noticed that at lower concentrations of GABA $(<30 \mu \mathrm{mol} / \mathrm{l})$, the amplitude of the GABA-evoked current $\left(\mathrm{I}_{\mathrm{GABA}}\right)$ was stable (not shown). However, at higher concentrations $(>100 \mu \mathrm{mol} / 1), \mathrm{I}_{\mathrm{GABA}}$ exhibited a rapid onset, characterised by a peak, followed by a gradual decay to a steady state (Fig. 2c, left). In response to $100 \mu \mathrm{mol} / 1$ GABA, the peak amplitude of the $\mathrm{I}_{\mathrm{GABA}}$ in individual cells varied from 12 to $470 \mathrm{pA}$ (Fig. $2 \mathrm{~d}$ ) (control $\mathrm{I}_{\mathrm{GABA}}$ : $117 \pm 33$ $\mathrm{pA}, n=15)$. Notably, $\mathrm{I}_{\mathrm{GABA}}$ could be reversibly suppressed by co-application of the competitive $\mathrm{GABA}_{\mathrm{A}} \mathrm{R}$ antagonist, bicuculline $\left(50 \mu \mathrm{mol} / 1\right.$; bicuculline $\mathrm{I}_{\mathrm{GABA}}: 7 \pm 2 \mathrm{pA}, n=4$; $p<0.05$ ) (Fig. 2d). These results demonstrate that the $\mathrm{GABA}_{\mathrm{A}}$ Rs in INS-1 cells are physiologically functional.

We further characterised the I- $V$ relationship of $\mathrm{GABA}_{\mathrm{A}^{-}}$ R-gated channels in INS-1 cells. GABA $(100 \mu \mathrm{mol} / \mathrm{l})$ was applied to cells held at different $V_{\mathrm{M}}$ levels ( -80 to $40 \mathrm{mV}$, see Fig. 2e) and the current was recorded. The plotted $I-V$ curve indicated that in the absence of extracellular glucose, $\mathrm{I}_{\mathrm{GABA}}$ reversed at $-42 \pm 2.2 \mathrm{mV}$ (Fig. $2 \mathrm{f}, n=6$ ). Glucose is one of the key physiological regulators of beta cell
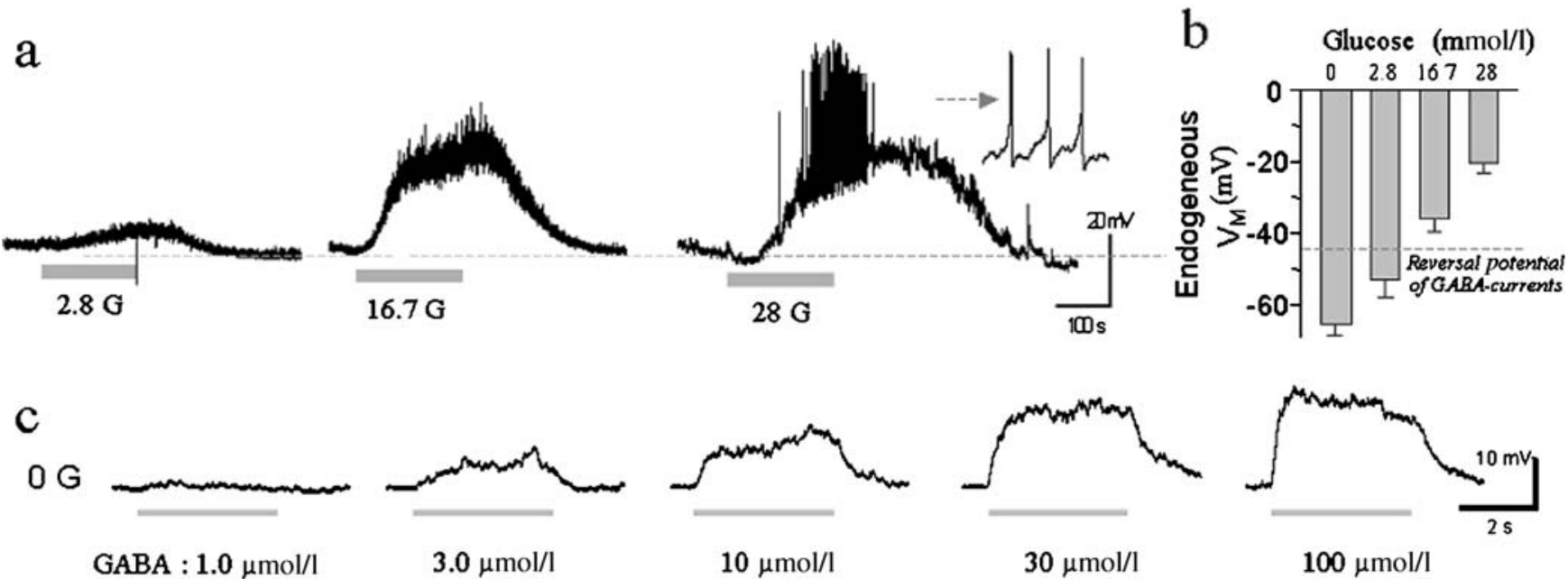

GABA : $1.0 \mu \mathrm{mol} / \mathrm{l}$ $3.0 \mu \mathrm{mol} / \mathrm{l}$ $10 \mu \mathrm{mol} / \mathrm{l}$ $30 \mu \mathrm{mol} / \mathrm{l}$
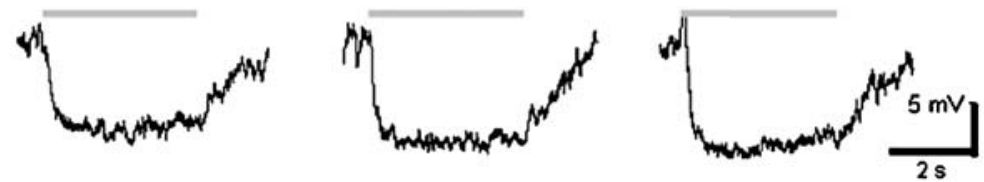

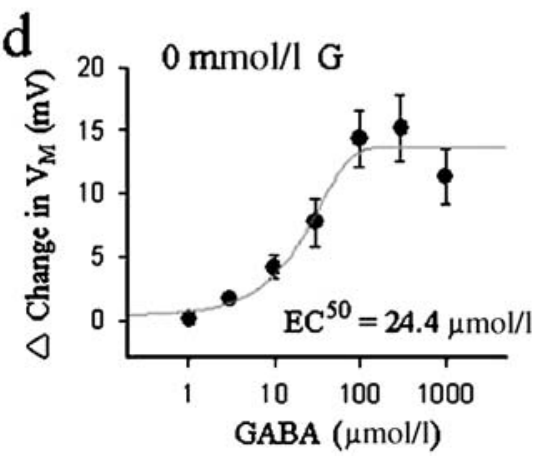

Fig. 3 Regulation of beta cell excitability by GABA in the presence of different concentrations of glucose. a Increase in glucose concentrations $(G)$ from $0 \mathrm{mmol} / 1$ to $2.8,16.7$ and $28 \mathrm{mmol} / \mathrm{l}$, caused a dose-dependent depolarisation of the cell (traces at 2.8, 16.7 and $28 \mathrm{G}$ were from the same cell). Note that bursting of action potentials was generated in some cells in the presence of high glucose $(\mathbf{c})$. b The membrane potentials $\left(\mathrm{V}_{\mathrm{M}}\right)$ of INS-1 cells in the presence of various concentrations of glucose are summarised (at $0 \mathrm{mmol} / \mathrm{l}:-65 \pm 3 \mathrm{mV}, n=12$; at $2.8 \mathrm{mmol} / 1:-53 \pm 2 \mathrm{mV}, n=6$; at $16.7 \mathrm{mmol} / \mathrm{l}:-32 \pm 2 \mathrm{mV}, n=7$; at $28 \mathrm{mmol} / \mathrm{l}:-22 \pm 2 \mathrm{mV}, n=6$ ).
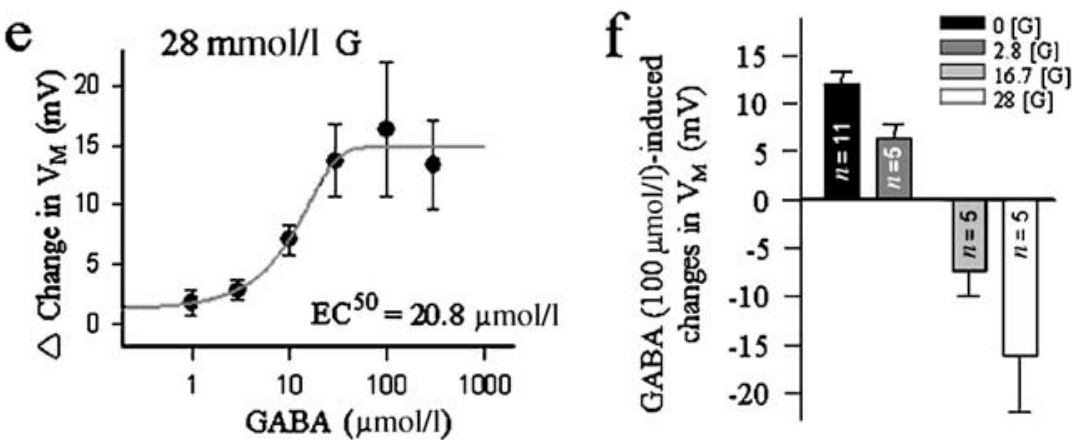

c Example traces illustrate the dose-dependent effect of GABA on $V_{\mathrm{M}}$ in the absence $(0 \mathrm{G})$, and presence of $28 \mathrm{mmol} / \mathrm{l}(28 \mathrm{G})$ of glucose. The grey bars under or above each trace indicate the duration of GABA perfusion. d, e Summarised data reveal the concentration-dependency of GABA on $V_{\mathrm{M}}$ in $0 \mathrm{mmol} / \mathrm{l}$ and $28 \mathrm{mmol} / \mathrm{l}$ of glucose, respectively. $\mathbf{f}$ Plotted graph indicates the direction and the scope of GABA-induced changes in $V_{\mathrm{M}}$ at different glucose concentrations ( $0 \mathrm{mmol} / \mathrm{l}: 10 \pm 1.2 \mathrm{mV}, n=11 ; 2.8 \mathrm{mmol} / \mathrm{l}: 6.5$ $\pm 0.7 \mathrm{mV}, n=5 ; 16.7 \mathrm{mmol} / \mathrm{l}:-8.5 \pm 5 \mathrm{mV}, n=5 ; 28 \mathrm{mmol} / \mathrm{l}:-16.0$ $\pm 5 \mathrm{mV}, n=5)$ 
functions. However, the reversal potential of $\mathrm{I}_{\mathrm{GABA}}$ in INS1 cells was not affected by addition of $16.7 \mathrm{mmol} / 1$ glucose to the extracellular solution (Fig. 2g), suggesting that glucose concentration does not affect this property of $\mathrm{GABA}_{\mathrm{A}} \mathrm{Rs}$, or the equilibrium potential of $\mathrm{Cl}^{-}$in INS-1 cells.

GABA regulates the excitability of INS-1 cells differently under different glucose concentrations

Glucose concentrations dictate the ratio of intracellular ATP/ADP concentrations, which in turn regulate the activity of ATP-sensitive $\mathrm{K}^{+}$(KATP) channels, thereby controlling the $V_{\mathrm{M}}$ of beta cells $[27,29-31]$. We tested the hypothesis that the level of glucose sets the instantaneous $V_{\mathrm{M}}$, which in turn determines the effect of $\mathrm{GABA}_{\mathrm{A}} \mathrm{R}$ activation on the excitability of beta cells. Using currentclamp recordings, we measured the change in $V_{\mathrm{M}}$ of INS-1 cells in response to increases of glucose concentration ( 0 to
$2.8,16.7$ or $28 \mathrm{mmol} / \mathrm{l}$, respectively, Fig. $3 \mathrm{a})$. In the absence of glucose, $V_{\mathrm{M}}$ of INS- 1 cells varied from -51 to $-82 \mathrm{mV}$ (Fig. $3 \mathrm{~b}:-65 \pm 3 \mathrm{mV}, n=12$ ). Increasing glucose concentrations depolarised the membrane of INS-1 cells in a concentration-dependent manner (Fig. 3a,b: $V_{\mathrm{M}}$ at $2.8 \mathrm{mmol} / 1$ glucose: $-53 \pm 2 \mathrm{mV} ; V_{\mathrm{M}}$ at $16.7 \mathrm{mmol} / \mathrm{l}:-32 \pm$ $2 \mathrm{mV} ; V_{\mathrm{M}}$ at $28 \mathrm{mmol} / \mathrm{l}:-22 \pm 2 \mathrm{mV}, n=6$ ). In some cases, bursts of action potentials were seen during high-glucoseinduced depolarisation (Fig. 3a).

Next, we examined the effect of different concentrations of GABA on $V_{\mathrm{M}}$ at low and high concentrations of glucose (Fig. 3c). GABA $(1-1,000 \mu \mathrm{mol} / 1)$ induced membrane depolarisation as a function of dose in the absence of glucose, but caused membrane hyperpolarisation in the presence of $28 \mathrm{mmol} / 1$ glucose (Fig. 3c). The $\mathrm{EC}_{50}$ value of GABA on $V_{\mathrm{M}}$ at low glucose was similar to that at high glucose ( $\mathrm{EC}_{50}$ at $0 \mathrm{mmol} / 1$ glucose: $24.4 ; \mathrm{EC}_{50}$ at $28 \mathrm{mmol} / 1$ glucose: $20.8 \mu \mathrm{mol} / 1$, Fig. $3 \mathrm{~d}$,e), suggesting that glucose does not affect the affinity of GABA for $\mathrm{GABA}_{\mathrm{A}}$ Rs. We further examined GABA $(100 \mu \mathrm{mol} / \mathrm{l})$-induced changes in
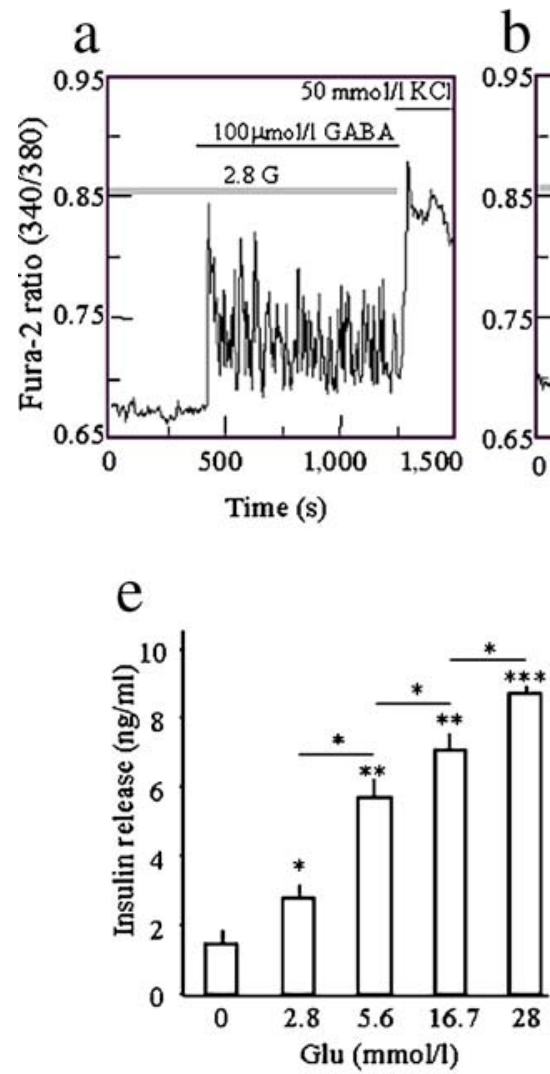
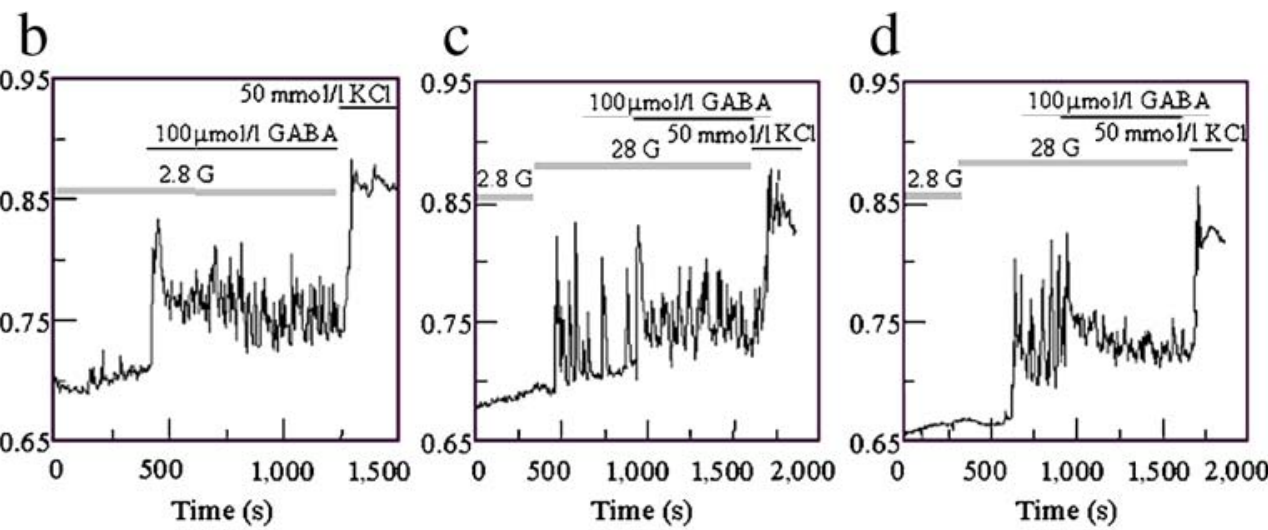
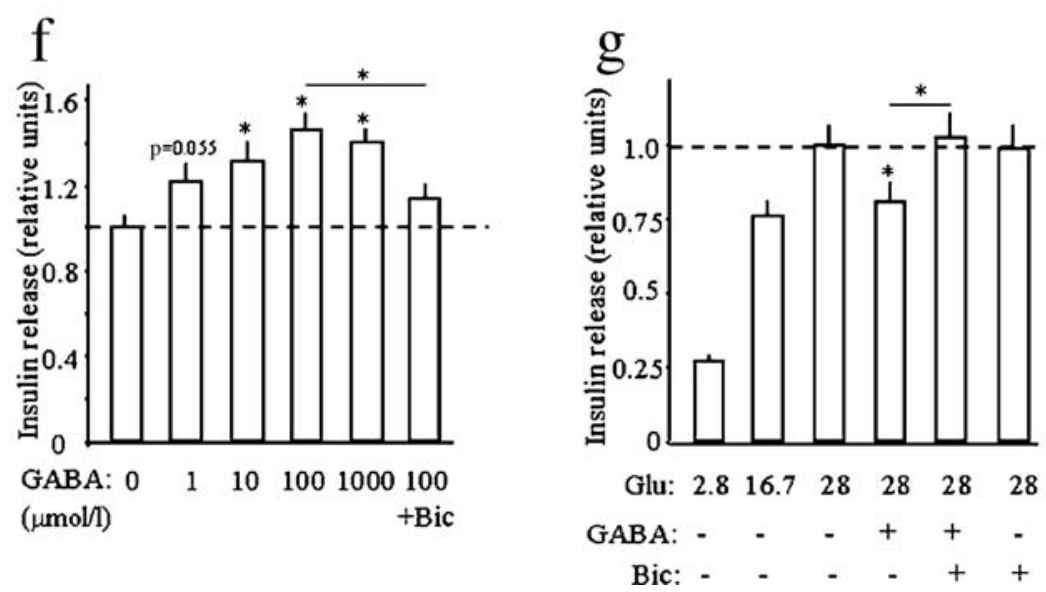

Fig. 4 Modulation of $\mathrm{Ca}^{2+}$ influx and insulin secretion by GABA in INS- 1 cells. a-d Effect of GABA $(100 \mu \mathrm{mol} / 1)$ on $\left[\mathrm{Ca}^{2+}\right]_{\mathrm{i}}$ in INS-1 cells. Cells grown on coverslips were loaded with Fura-2 AM and transferred to a chamber and perfused at $1 \mathrm{ml} / \mathrm{min}\left(36-37^{\circ} \mathrm{C}\right)$ as described in Materials and methods. Horizontal lines show perfusion with corresponding reagents; the glucose $(G)$ levels are outlined by the grey lines. The typical time-dependent $\left[\mathrm{Ca}^{2+}\right]_{\mathrm{i}}$ response from individual cells is shown and represents three independent experiments in which $30-50$ cells were measured from each experiment at low glucose $(\mathbf{a}, \mathbf{b}, 2.8 \mathrm{mmol} / \mathrm{l})$ or high glucose (c, d, $28 \mathrm{mmol} / \mathrm{l}$ ). e Glucose-stimulated insulin secretion is concentration-dependent $(n=4)$. Cells were incubated in KRB in the presence of various concentrations of glucose $(G l u)$ as indicated. After $30 \mathrm{~min}$ of incubation, the media were collected and insulin levels were measured by RIA. f In the presence of $2.8 \mathrm{mmol} / \mathrm{l}$ glucose, insulin secretion was measured in the presence of different concentrations of GABA $(n=7)$, with or without $\mathrm{GABA}_{\mathrm{A}} \mathrm{R}$ antagonist bicuculline (Bic, $100 \mu \mathrm{mol} / 1, n=4)$. g Effect of GABA $(100 \mu \mathrm{mol} / 1)$ and bicuculline $($ Bic, $100 \mu \mathrm{mol} / \mathrm{l})$ on insulin secretion at $28 \mathrm{mmol} / \mathrm{l}$ glucose $(G l u, n=4) .{ }^{*} p<0.05,{ }^{* *} p<0.01,{ }^{* * *} p<0.005$ 
$V_{\mathrm{M}}$ at $0,2.8,16.8$ and $28 \mathrm{mmol} / \mathrm{l}$ glucose, and confirmed that GABA could up- and downregulate the $V_{\mathrm{M}}$ of beta cells in accordance with glucose concentrations (Fig. 3f, at $0 \mathrm{mmol} / 1$ glucose: depolarisation $12 \pm 1.2 \mathrm{mV}, n=11$; at $2.8 \mathrm{mmol} / \mathrm{l}$ : depolarisation $6.5 \pm 0.7 \mathrm{mV}, n=9$; at $16.8 \mathrm{mmol} / \mathrm{l}$ : hyperpolarisation $-8.5 \pm 5 \mathrm{mV}, n=9$; at $28 \mathrm{mmol} / \mathrm{l}$ : hyperpolarisation $-16.0 \pm 5 \mathrm{mV}, n=9$ ).

GABA increases the cytosolic calcium concentration of INS-1 cells

Using fluorescent probe, Fura 2-AM, we measured $\left[\mathrm{Ca}^{2+}\right]_{\mathrm{i}}$ of individual INS-1 cells in response to GABA treatment. Perfusion of GABA $(100 \mu \mathrm{mol} / \mathrm{l})$ at low glucose $(2.8 \mathrm{mmol} / \mathrm{l})$ led to a significant increase of $\left[\mathrm{Ca}^{2+}\right]_{\mathrm{i}}$ (Fig. 4a,b: representative $\left[\mathrm{Ca}^{2+}\right]_{\mathrm{i}}$ of two individual cells). Presumably, this fact reflects depolarisation of the cells by GABA, because membrane depolarisation induced by increasing extracellular $\mathrm{KCl}$ (to $50 \mathrm{mmol} / \mathrm{l}$ ) also drastically elevated $\left[\mathrm{Ca}^{2+}\right]_{\mathrm{i}}$ of the INS-1 cells. In all cells tested, the increase of $\left[\mathrm{Ca}^{2+}\right]_{i}$ during GABA treatment displayed oscillatory behaviour (Fig. 4a,b, $n=3 ; 30-50$ cells were measured from each experiment). Perfusion of $28 \mathrm{mmol} / 1$ glucose led to a drastic increase in cytosolic $\mathrm{Ca}^{2+}$ oscillation (Fig. 4c,d). In this case, application of GABA $(100 \mu \mathrm{mol} / \mathrm{l})$ suppressed the amplitude of $\mathrm{Ca}^{2+}$ oscillation spikes (Fig. 4c,d). Nevertheless, an increase in the frequency of $\mathrm{Ca}^{2+}$ oscillation was observed in some cells (Fig. 4c).

GABA-modulated insulin secretion in INS-1 cells is dependent on glucose concentration

Next, we determined whether GABA affects insulin secretion in INS-1 cells using insulin secretion assays. Glucose stimulated insulin secretion from INS-1 cells in a dose-dependent manner (Fig. 4e). Consistent with the electrophysiological data, under low glucose conditions $(2.8 \mathrm{mmol} / \mathrm{l})$, GABA $(1-1,000 \mu \mathrm{mol} / \mathrm{l})$ steadily increased insulin secretion (Fig. 4f, $p<0.05, n=7$ ). This effect of GABA was significantly diminished by the $\mathrm{GABA}_{\mathrm{A}} \mathrm{R}$ antagonist bicuculline (Fig. 4f, $n=4$ ). In contrast, under high glucose conditions $(28 \mathrm{mmol} / \mathrm{l})$, GABA significantly suppressed insulin secretion (Fig. $4 \mathrm{~g}, p<0.05, n=5$ ). This suppression was also significantly attenuated by co-incubation of the cells with bicuculline (Fig. 4g, $p<0.05, n=4$ ). Bicuculline, by itself, had no significant effect on insulin secretion under low and high glucose conditions (Fig. 4f,g, $p>0.05, n=4)$. In contrast, the $\mathrm{GABA}_{\mathrm{B}} \mathrm{R}$ agonist, baclofen had no significant effect on GABA-modulated insulin secretion from INS-1 cells at either low $(2.8 \mathrm{mmol} / \mathrm{l})$ or high $(28 \mathrm{mmol} / \mathrm{l})$ glucose $(2.8 \mathrm{mmol} / \mathrm{l}$ : control vs. baclofen $=1.0 \pm 0.1$ vs. $0.98 \pm 0.09 ; 28 \mathrm{mmol} / \mathrm{l}$ : control vs. baclofen $=1 \pm 0.16$ vs. $1.12 \pm 0.19 ; p>0.05, n=3$ ). These results indicate that activation of $\mathrm{GABA}_{\mathrm{A}} \mathrm{R}$ up- and downregulates insulin secretion depending on the extracellular concentration of glucose.

\section{Discussion}

Previous studies [4-8] suggest that the pancreatic GABA$\mathrm{GABA}_{\mathrm{A}} \mathrm{R}$ system plays a role in modulating islet endocrine functions. However, the reported effects of GABA on insulin secretion from the beta cells have been controversial. In this study we demonstrated a mechanism by which GABA modulates insulin secretion from beta cells in concert with changes in glucose concentration.

We found that $\mathrm{GABA}_{\mathrm{A}} \mathrm{Rs}$ are expressed in the widely used beta cell line INS-1 cells (Fig. 1), which is consistent with previously reported studies in isolated human insulinoma cells [13] and rat pancreatic beta cells [15]. Since GABA is localised mainly within the pancreatic beta cells [32], identification of $\mathrm{GABA}_{\mathrm{A}} \mathrm{Rs}$ in the beta cells suggests that the GABA- $\mathrm{GABA}_{\mathrm{A}} \mathrm{R}$ system may serve as both an autocrine and paracrine modulator in the islets. We also demonstrated that, dependent on dose, perfusion of GABA induced transmembrane currents in INS-1 cells, and that the GABA-induced current was sensitive to the $\mathrm{GABA}_{\mathrm{A}} \mathrm{R}$ antagonist, bicuculline (Fig. 2a,c). These results indicate that $\mathrm{GABA}_{\mathrm{A}} \mathrm{Rs}$ in INS-1 cells are functional.

It is well known that by modulating the KATP conductance, glucose concentration critically sets the instantaneous $V_{\mathrm{M}}$ of beta cells [27]. We confirmed that with increasing glucose concentrations, from 0 to $28 \mathrm{mmol} / \mathrm{l}$, the $V_{\mathrm{M}}$ of INS- 1 cells changed from approximately $-65 \mathrm{mV}$ to approximately $-22 \mathrm{mV}$. On the other hand, we found that changing glucose concentrations did not affect the reversal potential of $\mathrm{GABA}_{\mathrm{A}} \mathrm{R}$-mediated currents, which was at about $-42 \mathrm{mV}$ in INS-1 cells. Therefore, activation of $\mathrm{GABA}_{\mathrm{A}} \mathrm{R}$ could potentially up- and downregulate the excitability of the cell, in accordance with changes in glucose concentrations. Indeed, our results demonstrated that while the cell membrane hyperpolarised in the presence of low glucose, application of GABA positively shifted the $V_{\mathrm{M}}$. In contrast, under conditions of high glucose, GABA negatively shifted the elevated $V_{\mathrm{M}}$. These data suggest that GABA, in concert with glucose, plays a role in regulation of excitability of the beta cell, thus regulating insulin secretion. This notion was strongly supported by the findings that GABA elevated the $\left[\mathrm{Ca}^{2+}\right]_{\mathrm{i}}$. oscillations at low glucose (Fig. 4a), but suppressed the amplitude of high-glucose-induced $\mathrm{Ca}^{2+}$-oscillation spikes (Fig. 4c).

Our insulin RIA results further confirmed that GABA stimulated insulin secretion at low $(2.8 \mathrm{mmol} / \mathrm{l})$ glucose, but inhibited insulin secretion at high $(28 \mathrm{mmol} / \mathrm{l})$ glucose. The bi-directional regulation of insulin secretion in beta cells by GABA at different glucose levels implies an important role for GABA in modulating islet hormonal secretion. GABA, by modulating insulin secretion from beta cells in concert with changes in glucose concentration, provides a unique mechanism for pancreatic endocrine regulation. Notably, in the presence of low glucose $(2.8 \mathrm{mmol} / \mathrm{l})$, GABA caused a moderate but significant increase in insulin secretion $(\sim 20-40 \%$, equivalent to 0.3-0.4 nmol/1). Intracellular $\mathrm{Ca}^{2+}$ measurements sug- 
gested that GABA-modulated insulin secretion in INS-1 cells may be via a mechanism involving $\mathrm{Ca}^{2+}$ movement.

Our findings in this study suggest that the GABA system may function as a negative feedback regulating mechanism in the islets. Under low glucose conditions, GABA release from beta cells increases [33, 34], which in turn may enhance insulin secretion. It has been demonstrated that insulin is a physiological inhibitor of glucagon release within islets [35] under in vitro [36, 37] and in vivo [38] conditions. Studies on islet microvasculature have shown that the alpha cells lie downstream from the beta cells, thus insulin released from beta cells can immediately act on alpha cells [39]. Therefore, physiologically, a modest change in insulin concentrations in the islet could have a significant impact on glucagon secretion from alpha cells. For instance, when hypoglycaemia occurs, GABA-stimulated insulin may act on the alpha cells to prevent the potential hyperglycaemia resulting from excessive glucagon secretion, because glucagon is a prominent facilitator of glucose production [40, 41]. Likewise, during hyperglycaemia, GABA depresses insulin secretion thus preventing a potential hypoglycaemia resulting from insulin 'overshooting'.

Acknowledgements This study was supported by research operating grants from the Canadian Institute for Health research (CIHR) to W.-Y. Lu, and to Q. Wang, respectively. H. Dong was supported by the Sunnybrook Trust Fellowship. M. Kumar is the recipient of the Canadian Diabetes Association Fellowship. W.-Y. Lu is a New Investigator of CIHR. Q. Wang is a recipient of a Canadian Diabetes Association Scholarship and is supported by New Investigator and Reuben \& Helene Dennis Scholar programs of the Banting and Best Diabetes Research Centre. The authors thank J. Ng for technical assistance. The authors are grateful to R. G. Tsushima, P. Brubaker (Department of Physiology, Medicine, University of Toronto) and P. Doherty (St Michael's Hospital, Toronto, Canada) for critical reading of the manuscript. H. Dong and M. Kumar contributed equally to this study.

\section{References}

1. Gottlieb DI (1988) GABAergic neurons. Sc Am 258:82-89

2. Kittler JT, McAinsh K, Moss SJ (2002) Mechanisms of $\mathrm{GAB}_{\mathrm{A}} \mathrm{A}$ receptor assembly and trafficking: implications for the modulation of inhibitory neurotransmission. Mol Neurobiol 26:251-268

3. Kittler JT, Moss SJ (2003) Modulation of $\mathrm{GAB}_{\mathrm{A}} \mathrm{A}$ receptor activity by phosphorylation and receptor trafficking: implications for the efficacy of synaptic inhibition. Curr Opin Neurobiol 13:341-347

4. Briel G, Gylfe E, Hellman B, Neuhoff V (1972) Microdetermination of free amino acids in pancreatic islets isolated from obese-hyperglycemic mice. Acta Physiol Scand 84:247-253

5. Garry DJ, Coulter HD, McIntee TJ, Wu JY, Sorenson RL (1987) Immunoreactive GABA transaminase within the pancreatic islet is localized in mitochondria of the B-cell. J Histochem Cytochem 35:831-836

6. Michalik M, Erecinska M (1992) GABA in pancreatic islets: metabolism and function. Biochem Pharmacol 44:1-9

7. Okada Y, Taniguchi H, Schimada C (1976) High concentration of GABA and high glutamate decarboxylase activity in rat pancreatic islets and human insulinoma. Science 194:620-622

8. Michalik M, Nelson J, Erecinska M (1993) GABA production in rat islets of Langerhans. Diabetes 42:1506-1513
9. Chessler SD, Simonson WT, Sweet IR, Hammerle LP (2002) Expression of the vesicular inhibitory amino acid transporter in pancreatic islet cells: distribution of the transporter within rat islets. Diabetes 51:1763-1771

10. Thomas-Reetz A, Hell JW, During MJ, Walch-Solimena C, Jahn R, De Camilli P (1993) A gamma-aminobutyric acid transporter driven by a proton pump is present in synaptic-like microvesicles of pancreatic beta cells. Proc Natl Acad Sci USA 90:5317-5321

11. Sorenson RL, Garry DG, Brelje TC (1991) Structural and functional considerations of GABA in islets of Langerhans. Beta-cells and nerves. Diabetes 40:1365-1374

12. Gilon P, Campistron G, Geffard M, Remacle C (1988) Immunocytochemical localisation of GABA in endocrine cells of the rat entero-pancreatic system. Biol Cell 62:265-273

13. Glassmeier G, Hopfner M, Buhr H et al (1998) Expression of functional $\mathrm{GAB}_{\mathrm{A}} \mathrm{A}$ receptors in isolated human insulinoma cells. Ann NY Acad Sci 859:241-248

14. Rorsman P, Berggren PO, Bokvist K et al (1989) Glucoseinhibition of glucagon secretion involves activation of $\mathrm{GAB}_{\mathrm{A}} \mathrm{A}$ receptor chloride channels. Nature 341:233-236

15. Von Blankenfeld G, Turner J, Ahnert-Hilger G et al (1995) Expression of functional $\mathrm{GAB}_{\mathrm{A}} \mathrm{A}$ receptors in neuroendocrine gastropancreatic cells. Pflugers Arch 430:381-388

16. Gu XH, Kurose T, Kato S et al (1993) Suppressive effect of GABA on insulin secretion from the pancreatic beta-cells in the rat. Life Sci 52:687-694

17. Satin LS, Kinard TA (1998) Neurotransmitters and their receptors in the islets of Langerhans of the pancreas: what messages do acetylcholine, glutamate, and GABA transmit? Endocrine 8:213-223

18. Shi Y, Kanaani J, Menard-Rose V et al (2000) Increased expression of GAD65 and GABA in pancreatic beta-cells impairs first-phase insulin secretion. Am J Physiol Endocrinol Metab 279:E684-E694

19. Smismans A, Schuit F, Pipeleers D (1997) Nutrient regulation of gamma-aminobutyric acid release from islet beta cells. Diabetologia 40:1411-1415

20. Winnock F, Ling Z, De Proft R et al (2002) Correlation between GABA release from rat islet beta-cells and their metabolic state. Am J Physiol Endocrinol Metab 282:E937-E942

21. Kawai, Unger RH (1983) Effects of gamma-aminobutyric acid on insulin, glucagon, and somatostatin release from isolated perfused dog pancreas. Endocrinology 113:111-113

22. Gilon P, Bertrand G, Loubatieres-Mariani MM, Remacle C, Henquin JC (1991) The influence of gamma-aminobutyric acid on hormone release by the mouse and rat endocrine pancreas. Endocrinology 129:2521-2529

23. Robbins MS, Grouse LH, Sorenson RL, Elde RP (1981) Effect of muscimol on glucose-stimulated somatostatin and insulin release from the isolated, perfused rat pancreas. Diabetes 30:168-171

24. Adeghate E, Ponery AS (2002) GABA in the endocrine pancreas: cellular localization and function in normal and diabetic rats. Tissue Cell 34:1-6

25. Gomez R, Asnis N, Tannhauser SL, Barros HM (1999) GABA agonists differentially modify blood glucose levels of diabetic rats. Jpn J Pharmacol 80:327-331

26. Maechler P, Wollheim CB (2001) Mitochondrial function in normal and diabetic beta-cells. Nature 414:807-812

27. Merglen A, Theander S, Rubi B, Chaffard G, Wollheim CB, Maechler P (2004) Glucose sensitivity and metabolism-secretion coupling studied during two-year continuous culture in INS-1E insulinoma cells. Endocrinology 145:667-678

28. Wang Q, Li L, Xu E, Wong V, Rhodes C, Brubaker PL (2004) Glucagon-like peptide-1 regulates proliferation and apoptosis via activation of protein kinase B in pancreatic INS-1 beta cells. Diabetologia 47:478-487

29. Ashcroft FM, Ashcroft SJ, Harrison DE (1988) Properties of single potassium channels modulated by glucose in rat pancreatic beta-cells. J Physiol 400:501-527 
30. Theler JM, Mollard P, Guerineau N et al (1992) Video imaging of cytosolic $\mathrm{Ca}^{2+}$ in pancreatic beta-cells stimulated by glucose, carbachol, and ATP. J Biol Chem 267:18110-18117

31. Ashcroft FM, Rorsman P (1989) Electrophysiology of the pancreatic beta-cell. Prog Biophys Mol Biol 54:87-143

32. Reetz A, Solimena M, Matteoli M, Folli F, Takei K, De Camilli P (1991) GABA and pancreatic beta-cells: colocalization of glutamic acid decarboxylase (GAD) and GABA with synapticlike microvesicles suggests their role in GABA storage and secretion. EMBO J 10:1275-1284

33. Hayashi M, Yamada H, Uehara S et al (2003) Secretory granule-mediated co-secretion of L-glutamate and glucagon triggers glutamatergic signal transmission in islets of Langerhans. J Biol Chem 278:1966-1974

34. Uehara S, Muroyama A, Echigo N et al (2004) Metabotropic glutamate receptor type 4 is involved in autoinhibitory cascade for glucagon secretion by alpha-cells of islet of Langerhans. Diabetes 53:998-1006

35. Maruyama H, Hisatomi A, Orci L, Grodsky GM, Unger RH (1984) Insulin within islets is a physiologic glucagon release inhibitor. J Clin Invest 74:2296-2299
36. Kaneko K, Shirotani T, Araki E et al (1999) Insulin inhibits glucagon secretion by the activation of PI3-kinase in In-R1-G9 cells. Diabetes Res Clin Pract 44:83-92

37. Kisanuki K, Kishikawa H, Araki E et al (1995) Expression of insulin receptor on clonal pancreatic alpha cells and its possible role for insulin-stimulated negative regulation of glucagon secretion. Diabetologia 38:422-429

38. Greenbaum CJ, Havel PJ, Taborsky GJ Jr, Klaff LJ (1991) Intra-islet insulin permits glucose to directly suppress pancreatic A cell function. J Clin Invest 88:767-773

39. Bonner-Weir S, Orci L (1982) New perspectives on the microvasculature of the islets of Langerhans in the rat. Diabetes 31:883-889

40. Raskin P, Unger RH (1978) Hyperglucagonemia and its suppression. Importance in the metabolic control of diabetes. N Engl J Med 299:433-436

41. Johnson DG, Goebel CU, Hruby VJ, Bregman MD, Trivedi D (1982) Hyperglycemia of diabetic rats decreased by a glucagon receptor antagonist. Science 215:1115-1116 